\title{
АНАЛІЗ МОЖЛИВОСТЕЙ ВПРОВАДЖЕННЯ Е-КВИТКА В НАЗЕМНОМУ ГРОМАДСЬКОМУ ТРАНСПОРТІ
}

\begin{abstract}
У статті надано науково обтрунтовані з економічної точки зору рекомендачії щцодо впровадження електронного квитка на підприємствах електротранспорту Украӥни на основі передових світових досягнень. Рекомендації, щуо трунтуються на наукових здобутках, нададуть допомогу українським містам (всім ланкам, задіяним в изьому процесі - міським радам, транспортним підприємствам та пасажирам) ефективно та в найкоротші строки запровадити та освойти електронний квиток та значно прискорити його адаптацію до украӥнських реалій.
\end{abstract}

Ключові слова: електронний квиток, автоматизована система оплати проїду, громадський транспорт.

Постановка проблеми. На підприємствах житлово-комунального господарства країни, а міських транспортних підприємств це стосується у першу чергу, бракує узагальнених науково обгрунтованих рекомендацій по визначенню організаційних змін. Чітко визначена концепція, яка 6 дозволила керівництву підприємства сформувати механізм проведення організаційних змін, передбачити можливі ризики й оцінити їх наслідки, практично відсутня. Важливим чинником $€$ удосконалення наукового підгрунтя проведення організаційних змін, що обумовлює необхідність формулювання сукупності положень та методичних принципів і підходів, які повинні бути покладені в основу впровадження е-квитка.

Особливості підприємств різних міст України, що здійснюють міські пасажирські перевезення, не допускають типових рішень. Уніфікованим може бути тільки методичній підхід впровадження електронного квитка. Концепція його впровадження передбачає чітко визначені цілі, завдання та обгрунтування, та повинна спиратися на стійке наукове підгрунтя, складовими якого $\epsilon$ принципи, прийоми, методи, управлінські технології, система критеріїв та показників.

Аналіз останніх досліджень і публікацій. 3 метою обгрунтування найбільш прийнятного для українського суспільства варіанту організації сплати проїзду в громадському транспорті авторами проведені дослідження та аналіз систем

(C) Водовозов Свгеній Наумович, здобувач, Харківський національний університет міського господарства імені О.М.Бекетова, м. Харків, тел.: 0973338883, email: evodovozov@gmail.com

Палант Олексій Юрійович, д.е.н., доцент, Харківський національний університет міського господарства імені О.М.Бекетова, м. Харків, тел.: 0503255192, email: kharget@gmail.com електронних розрахунків на транспорті в різних країнах світу, ї економічної доцільності та можливостей застосування в правовому полі України.

Виявлено, що протягом останніх 20-25 років у світі створено понад сто різних автоматизованих систем оплати проїзду (зокрема продемонстрованих в [1-3]), які дозволяють пасажиру оплатити послугу простіше, швидше $\mathrm{i}$ зручніше, а транспортній компанії - збільшити прибуток за рахунок підвищення точності обліку оплати проїзду. Треба зазначити, що подібною проблематикою була спантеличена невелика кількість фахівців, причетних до цієї області досліджень, серед них [4-12].

Формулювання цілей статті. Проведені дослідження, що знайшли висвітлення в статті, ставили за мету провести аналіз, визначити особливості та можливість впровадити в нашій країни електронні системи оплати проїзду в громадському транспорті за допомогою безконтактних карток та інших засобів оплати.

Отже впровадження електронного квитка на громадському транспорті тісно пов'язано 3 сутнісним аспектом, який випливає 3 мотиваційної орієнтації підприємств. Для досягнення цієї мети комунальні підприємства мають низку специфічних агрегованих цілей, серед яких: підвищення рівня якості надаваємих послуг; створення ринку якісних послуг; забезпечення комплексності послуг; подальший інноваційний розвиток послуг та підвищення науково-технічного рівня виробництва послуг; забезпечення конкурентоздатності підприємств.

Опис основного матеріалу досліджень. Досвід економічно розвинутих країн свідчить, що для покращення економічної ситуації в державі в цілому рівно, як і на окремому підприємстві, необхідно поєднання науки 3 практикою, системних знань 3 механізмами 
управління, політики 3 економікою. Одним 3 інститутів життєзабезпечення населення є система житлово-комунального господарства, до складу якої входить міська громадська транспортна інфраструктура. Підприємства цієї галузі роззміщені у великих i малих містах країни 3 більш-менш значною щільністю населення та значною концентрацією продуктивних сил. Транспорт, як відомо, забезпечує свободу переміщення. Транспортні послуги є платними. Плата за надані послуги одне 3 джерел наповнення бюджету транспортних підприємств, які в свій більшості були й залишаються збитковими (дотаційними). Для виведення 3 такого незавидного становища, серед інших, є рішення щодо введення в усіх містах, де функціонує міський громадський транспорт, автоматизованої системи оплати проїзду (АСОП).

Наведемо для прикладу два міста 3 різною ситуацію зі збором виручки від реалізації квитків. Це міста Херсон, де найнижчий відсоток покриття витрат за рахунок реалізації квитків 14,4 \%, та Вінницю, де цей показник найвищий в Україні і доходить до 61,3 \%. Пояснити це можна в такий спосіб. По-перше, у Вінниці електротранспорт абсолютно домінує в структурі міських пасажироперевезень. Зокрема, він займає близько 70-75 \% від їх загального обсягу. Місцева влада змогла утримати всі показники роботи з 1990 року, і більш того, за рахунок часткової модернізації парку і ввезення бүу трамваїв ці показники наростити. Електротранспорт у Вінниці користується величезною популярністю у населення, добре організований і має інтервал руху 1-2 (!) хвилини в години пік. Крім того, у Вінниці відсутні дублюючі маршрути, отже основний контингент пасажирів по факту платить комунальному підприємству. У Херсоні ситуація зворотна - основними перевізниками $є$ приватні автотранспортні підприємства, а по-друге, відповідно до даних Держстату, в Херсоні та Вінниці абсолютно різні демографічні ситуації: кількість пільгового контингенту щодо кількості платних пасажирів в Херсоні майже в два рази більша, ніж у Вінниці.

Для покращення ситуації пропонується створення окремого суб'єкта господарювання для обслуговування АСОП, який буде призваний забезпечити їі впровадження та експлуатацію для всіх міст України з урахування їх специфічних умов.

У світовій практиці використовуються три моделі управління міським транспортом: адміністративна (США, Канада, Франція), модель регульованого ринку (країни Скандинавії, Чехія, Польща, країни Прибалтики), вільного ринку
(Великобританія, Чилі). Найбільш поширена модель «регульованого ринку». У країнах, де діє така модель, частка дотаційних витрат значно менша, ніж в інших (30-40\%), і вона поступово зменшується. У багатьох містах Європи рівень покриття витрат виручкою від оплати за проїзд досягає $80 \%$ А ось Парижі, де діє адміністративна модель, ця складова покриття витрат не перевищує 25-30\%.

Нам найбільш близька модель регульованого ринку. У практиці найбільш цікавим здається досвід Чехії, Польщі та Прибалтики, де, з одного боку, електротранспорт традиційно розвинений i затребуваний у великих і середніх містах, а 3 іншого боку, ці країни вже повністю або частково пройшли весь шлях, який нам ще тільки належить пройти.

Міністерство інфраструктури України створило Робочу групу, забов'язавши ії взяти на себе кураторство щодо впровадження АСОП (i основної пї ланки - електронного квітка) на громадському транспорті в більшості міст країни, де цей транспорт функціонує. Таких міст налічується понад 25. Первісним результатом роботи групи стала доповідь, що розкриває готовність, потреби та специфіку міст України щодо впровадження електронного квитка. Вона також висвітлила «основи системи електронного продажу квитків на міському та національному рівнях», яка повинна підвищити ефективність функціонування транспортних підприємств шляхом підвищення ефективності збору виручки. Гнучкі принципи продажу засобів оплати проїзду повинні привести пасажирів до вибору громадського транспорту замість використання інших засобів пересування.

Ми пропонуємо надавати пасажирам вибір: якомога більше засобів оплати проїзду, а не зосереджуватися лише на одному чи декількох. Це можуть бути паперові одноразові чи на фіксовану кількість поїздок квитки, жетони, безконтактні транспортні картки, банківські картки, оплата QR-кодом за допомогою мобільних телефонів та споріднених електронних пристроїв (годинників, браслетів, окулярів тощо). Такі різноманітні способи оплати також призвані зробити привабливим громадський транспорт для гостей міст, коли не виникатиме проблем із купівлею засобів оплати пересування та наявністю місцевої валюти або відсутністю дрібних купюр. Електронні транспортні квитки, а саме вони, на нашу думку, стануть наймасовішим засобом оплати проїзду в громадському транспорті, будуть згодом передбачати спеціальні тарифи на дальність поїздок (зонування), на пересадність (можливість використання квитка на декількох видах 
транспорту протягом певного часу), на час доби, на пору року, на кількість передплачених поїздок, кількість пасажирів, що можуть одномоментно використовувати квиток, тривалість часу, на протязі якого він діє, тощо.

Безконтактні картки мають бути із достатнім рівнем захисту від підробок (клонування, фальсифікації) та 3 достатнім рівнем стійкості до поломок. Вони також повинні мати гнучкі, нетривалі в часі, різноманітні та надійні способи поповнення. Саме транспортні картки міститимуть інформацію про пільги, надані пасажирам окремих категорій державою або місцевою владою.

Комунальні підприємства-постачальники транспортних послуг з введенням е-квитка не тільки оптимізують свої послуги та якомога більше задовольнять потреби пасажирів, а й зменшать збитки за рахунок більш повного збору плати за проїзд та персоніфікації пільгового контингенту, що впливає на розподіл та отримання субсидій (компенсацій) перевізниками.

Реальна інформація, надходження якої з системи АСОП практично не може бути сфальсифікована, дасть уряду та органам місцевого самоврядування можливість оптимізувати бюджетні витрати на цей сектор економіки.

Впровадження АСОП в наземному міському транспорті вимагає обладнання транспортних засобів транспортними терміналами (валідаторами). Їх вигляд, модифікації і умови використання повинні бути визначені в договорі про організацію надання транспортних послуг із замовником таких послуг - органами місцевого самоврядування. У зазначений договір також рекомендовано включити умови фінансування придбання i установки таких терміналів в рухомому складі. Існує кілька моделей врегулювання питань фінансування:

1) укладення прямих договорів поставки (купівлі-продажу) між транспортним управлінням органу місцевого самоврядування й виробником транспортних терміналів 3 включенням в предмет договору умов по їх установці та обслуговуванню;

2) договір купівлі-продажу укладається між перевізником і виробником транспортних терміналів, при цьому замовник транспортних послуг (міськрада) компенсує перевізнику вартість витрат, пов'язаних 3 придбанням та установкою терміналів на умовах, визначених у договорі про організацію надання транспортних послуг. Умови компенсації можуть варіюватися від перерахування коштів на рахунок перевізника у вигляді повної або часткової передоплати до оплати за фактом закупівлі терміналів;

3) між оператором АСОП, перевізником і виробником транспортних терміналів укладається договір лізингу, за яким покупцем (лізингодавцем) терміналів буде виступати оператор АСОП, він здійснює оплату та надає їх у користування перевізнику за умови сплати лізингових платежів 3 правом подальшого їх викупу. При такій моделі врегулювання відносин придбання i установки транспортних терміналів після сплати їх повної вартості у вигляді лізингових платежів перевізник набуває право власності на термінали.

Кількість валідаторів, встановлених на рухомому складі, повинна буди достатньою для забезпечення швидкої, безперешкодної та безпечної посадки-висадки пасажирів. Інакше це, крім загрози життю та здоров'ю пасажирів, негативно вплине на якість надаваної транспортної послуги та приведе до збою графіків руху через невиправдані затримки на зупинках.

3 цих же причин швидкість спрацювання валідаційних пристроїв та швидкості здійснення транзакцій дуже важлива.

Висновки та перспективи подальших досліджень. Поза межами статті залишилися питання диспетчеризації громадського транспорту та питання інформатизації. Це теми наступних досліджень та публікацій авторів. Диспетчеризація - це система не тільки управління транспортним рухом, а й система управляння транспортним парком, відстеження транспортного засобу на маршруті. Вона передбачає фіксацію, аналіз та оцінювання багатьох параметрів - від швидкості та дотримання графіків руху рухомим складом до відстеження інтенсивності пасажиропотоку. Вона покликана не тільки проводити моніторинг в реальному часі, але й аналізувати, оцінювати та реагувати на виникнення різних позаштатних подій аж до надзвичайних ситуацій та оперативно проводити, наприклад, оптимізацію маршрутної мережі. Зараз автори розробляють методологію, що об'єднає всі вищеперелічені питання диспетчеризації руху транспортних засобів.

В завершенні статті автори наголошують, що реалізація комплексної та науково обгрунтованої системи е-квитків в громадському транспорті $\epsilon$ вкрай необхідною та назрілою проблемою та $є$ безпрограшним варіантом для всіх трьох зацікавлених сторін міських пасажирських перевезень - пасажирів, транспортних компаній та місцевих органів влади.

\section{ПЕРЕЛІК ВИКОРИСТАНИХ ДЖЕРЕЛ}

1. Автоматизированная система оплаты проезда [Електронний ресурс] // LOT Group - Режим доступу до 
pecypcy: http://lotgroup.eu/ru/product/smart-city/afc/

2. Автоматизована система оплати проїзду CS-Trans ${ }^{\circledR}$ [Електронний ресурс] // КАРД-СICTЕМС® - Режим доступу до ресурсу: https://card-sys.com/products/Avtomatizovana_sistema_oplati_prozdu_CS-Trans

3. Автоматизированная система оплаты и контроля проезда [Електронний ресурс] // belcard.by - Pежим доступу до ресурсу: http://www.belcard.by/smart-systems/asokp/

4. Адаменко М. I. Економіко-технічна надійність експлуатації міського електричного транспорту / I.М. Адаменко, О.Ю. Палант. - Харків : Золоті сторінки, 2014. - 144 с.

5. Вакуленко К.С. Особливості управління міськими пасажирськими транспортними системами / К. Вакуленко, К. Доля. - Харків : НТМТ, 2013. - 171 с.

6. Аистова М.Д. Реструктуризация предприятий: вопросы управления, стратегии, координации структурных параметров, снижение сопротивления преобразования / М.Д. Аистова - М.: Альпина Паблишер, 2012. - 287 с.

7. Водачек Л.П. Реструктуризация - вызов чешским предприятиям / Л.П. Водачек // Проблемы теории и практики управления. - 2010. - №1. - С. 84-89.

8. Евсеев А.С. Стратегия реструктуризации предприятий в условиях кризисной ситуации / А.С. Евсеев // Проблемы теории и практики управления. -2009. - №3. - С. 109-113.

9. Палант О.Ю. Інноваційне впровадження автоматизованої системи оплати проїзду в мегаполісах України / О.Ю. Палант // Актуальні питання інтелектуальної власності та інноваційного розвитку : матеріали міжнародн. наук.-практич. конф., 3-5 квітн. 2012 р. - Харків, 2012. - С. 338-341.

10. Дивінець О.Л. Економіко-правові аспекти впровадження автоматизованих систем оплати проїзду в наземному електротранспорті України / О.Л. Дивінець, О.Ю.Палант. - Львів : ТОВ «Ліга-прес», 2015. - 192 с.

11. Водовозов Є.Н. Моделювання процесів стратегічної реструктуризації підприємств сфери ЖКГ / Є.Н.Водовозов // Інвестиції: практика і досвід. - 2012. - № 20. - С.53-59.

12. Водовозов Є.Н. Реструктуризація підприємств сфери ЖКГ на основі проектного підходу / Є.Н.Водовозов // Вісник Житомирського державного технологічного університету. - 2012. - № 3 (61). - С. 215-218.

\section{REFERENCES}

1. http://lotgroup.eu/

2. http://card-sys.com/

3. http://www.belcard.by/

4. Adamenko, M.I. and Palant, O.Y. (2014), Ekonomiko-tekhnichna nadiinist ekspluatatsii miskoho elektrychnoho transport [Economic and technical reliability of operation of public electric transport], Zoloti storinky, Kharkiv, Ukraine, $144 \mathrm{p}$.

5. Vakulenko, K.E. and Dolia, K.V. (2013), Osoblyvosti upravlinnia miskymy pasazhirskymy transportnymy systemamy [Features of management of urban passenger transport systems], monograph, NTMT, Kharkiv, Ukraine, $171 \mathrm{p}$.

6. Aistova, M.D. (2012), Restrukturizatsiya predpriyatiy: voprosy upravleniya, strategii, koordinatsii strukturnyh parametrov, snizhenie soprotivleniya preobrazovaniya [Restructurization of enterprises: management, strategy, coordination of structural parameters, drag reduction of transformation], Alpina pablisher, Moscow, Russia, 287 p.

7. Vodachek, L.P. (2010), Restrukturizatsiya - vyzov cheshskim predpriyatiyam, problemy teorii $i$ praktiki upravleniya [Restructurization-challeng the Czech enterprises, problems of the theory and practice of management], no.1, pp.84-89.

8. Yevseev, A.S. (2009), Strategiya restrukturizatsii predpriyatiy v usloviyakh krizisnoy situatsii, problemy teorii $i$ praktiki upravleniya [The restructurization strategy of enterprise in crisis, problems of the theory and practice of management], no.3, pp.109-113.

9. Palant, O.Y. (2012), Innovatsiyne vprovadzhennya avtomatyzovannoi systemy oplatu proizdu v mehapolisah Ukrainy/ Materialy Mizhnarodnoi naukovo-praktychnoi konferentsii "Aktualni pytannia intelectualnoi vlasnosti ta innovatsiynoho rozvytku" [nnovative introduction of automated fare system in metropolitan areas of Ukraine // International scientific conference "Current problems of intellectual property and innovation"], Kharkiv, pp. 338 - 341.

10. Dyvinets, O.L., Palant, O.Y., (2015), Ekonomiko-pravovi aspekty vprovadzhennya avtomatyzovannukh system oplaty proizdy $\mathrm{v}$ nazemnomu elektrotransporti Ukrainy [Economic and legal aspects of the implementation of automated fare ground electric transport of Ukraine], TOV "Liga-pres", Lviv, p. 192.

11. Vodovozov, E.N. (2012), Modeliuvannia protsesiv strategichnoi restrukturizatsii pidpryiemstv sfery ZKG [Modeling of the strategic restructurization of enterprises in the sphere of housing and communal services], Investitsii: praktyka i dosvid. (Sci.-Tech.) collected works, Chornomorskyi derzhavnyi universytet im. Petra Mogyly, no.20, Odessa, Ukraine pp.53-59.

12. Vodovozov, E.N. (2012), Restrukturizatsiya pidpryiemstv sfery ZKG na osnovi proektnogo pidhodu [Restructurization of enterprises of housing and communal services based on project approach] Visnyk Zhytomirskogo tekhnologichnogo universytetu. Naukovyi zhurnal, seriya: Ekonomichni nauky, no. 3 (61), Zhytomir, Ukraine, pp. 215218.

Одержано 04.03.2018 p. 